\begin{tabular}{|c|c|c|c|c|}
\hline JURNAL & \multirow{2}{*}{ VOLUME 2} & \multirow{2}{*}{ NOMOR 1 } & HALAMAN 1-73 & $\begin{array}{l}\text { ISSN 2655-8823 }(p) \\
\text { ISSN 2656-1786 }(e)\end{array}$ \\
\hline
\end{tabular}

\title{
SOCIALIZATION OF LAW NUMBER 7 OF 2012 ABOUT MANAGING OF SOCIAL CONFLICTS AS EFFORTS TO CREATE A HARMONIOUS ENVIRONMENT IN GENTENG VILLAGE, SUKASARI SUBDISTRICT SUMEDANG REGENCY
}

\author{
Soni Akhmad Nulhaqim \\ Lecturer of Prodi Kesejahteraan Sosial FISIP Unpad \\ E-mail: soni.nulhaqim@unpad.ac.id \\ Muhammad Fedryansyah \\ Lecturer of Prodi Kesejahteraan Sosial FISIP Unpad \\ E-mail: m.fedryansyah@unpad.ac.id \\ Eva Nuriyah Hidayat \\ Lecturer of Prodi Kesejahteraan Sosial FISIP Unpad \\ E-mail: eva.nuriyah@unpad.ac.id
}

\begin{abstract}
ABSTRACK
Community Service Activities (PPM) in Genteng Village, Sukasari Subdistrict, Sumedang Regency was initiated because the agrarian conflict had happened in that location. The conflict resolution were relatively slow due to the lack of understanding, knowledge and skills of the actors in conducting conflict resolution. In contrary, conflict resolution is clearly written in Law Number 7 of 2012 about Managing of Social Conflict. In addition, the location of PPM also has a high potential for conflicts, especially conflicts in the use of natural resources. This must be anticipated by encouraging existing communities and local institutions to work together to prevent conflict and create a harmonious environment. The purpose of this PPM activity is to increase the knowledge, understanding and skills of target groups in conducting conflict resolution based on Law No. 7 of 2012 about Managing of Social Conflict, to increase the knowledge, understanding and skills of target groups in conducting community-based conflict resolution and to encourage target groups to prevent conflicts and can creat a harmony in the village. The target groups in this PPM activity are the farming community, village government and local institutions in the Genteng Village. The method of implementing PPM activities was conducted in several stages, such as the preparation phase, the assessment stage, the plan of treatment stage, and the activity implementation stage.
\end{abstract}

Keywords: conflict, conflict management, conflict resolution, Managing of Social Conflict Law.

\section{BACKGROUND}

Genteng Village is one of the villages located in Sukasari District, Sumedang Regency. This Genteng village is located at an altitude of 750-1,200 meters above sea level with an area of $\pm 1,300$ hectares. Administratively, the northern part of Genteng Village is directly bordering with East Manglayang Perhutani Forest. In the south, it is bordering with Sukasari Village, in the east, it is bordering with Kadakajaya Village, Tanjungsari District and in the west it borders Banyuresmi Village.
Based on data from the Genteng Village Profile for 2019, the projected population of Genteng Village in 2018 is 6,039 people with a total of 2,217 households. The livelihoods of people in Genteng Village are farmers and ranchers. The number of people whose livelihoods as farmers are 2,509 people, with detail 723 of them as farmers in agricultural sector and the rest is 1,332 as ranchers. The area of agricultural land in Genteng Village is $1,300 \mathrm{Ha}$ with a total of $314 \mathrm{Ha}$ of Paddy Field, $354 \mathrm{Ha}$ of Settlement Area, $282 \mathrm{Ha}$ of Productive Land, $300 \mathrm{Ha}$ 


\begin{tabular}{|c|c|c|c|c|}
\hline JURNAL & \multirow{2}{*}{ VOLUME 2 } & \multirow{2}{*}{ NOMOR 1 } & HALAMAN 1-73 & $\begin{array}{l}\text { ISSN 2655-8823 }(p) \\
\text { ISSN 2656-1786 }(e)\end{array}$ \\
\hline
\end{tabular}

of State Plantation, and $50 \mathrm{Ha}$ for other function. Not all of people who make a living as farmers have their own cultivation land, they rent it to a landlord or even Indonesian State Plantation Company (Perum Perhutani). The agricultural commodities in Genteng Village are cabbage, red chili, it has cows, sheep, and chickens. Aside from being a farmer and rancher, the people also have other livelihoods such as traders, laborers, factory employees, civil servants / military, and entrepreneurs.

This PPM activity is integrated with a research entitled Agraria Conflict Resolution Model Based on Community in Farming Communities. Based on research that has been conducted, it was found that in the Genteng Village, there had been an agrarian conflict. Agrarian conflict is basically a conflict that happens as result of relations between people or groups to the problems of natural resources, either those are found on the earth or inside of it (Zakie, 2016). Furthermore, according to Chandra (1992: 20) that conflict can happen due to the differences in interests between communities. This also happened in Genteng Village, an agrarian conflict that have happened caused by differences in interest in land use between Perum Perhutani and the farming community.

The majority of people in Genteng Village work as farmers, thus they need agricultural land for farming. Meanwhile, not all of them have privately owned agricultural land, so they rent agricultural land owned by others. Others use abandoned land owned by Perum Perhutani which is directly bordering to their village. This agrarian conflict arised when Perum Perhutani attempted to take over agricultural land as a forest conservation area, in order to protect the ecosystem in the area. However, the farmers did not accept the decision by Perhutani, because their main source of livelihood would be lost. In addition, for local farmers, aside from being a source of livelihood, the forest area was also used as expanding cultivation land, and also as a food security area for them (Permadi, 2016: 226). The nature function of forest for local farmers caused different interests in land use which is the cause of agrarian conflicts between farmers and Perum Perhutani.

Several attempts were made to resolve agrarian conflicts between Perum Perhutani and the farming community in the Genteng Village. Farming communities that were accommodated by local institutions such as farmer groups, Genteng Village government and nongovernmental organizations in the Genteng Village have made various conflict resolution efforts to resolve the agrarian conflict. Until finally an agreement was reached that the farming community could do farming activities in the forest area, but with certain types of plants, such as the hard one. Through this agreement, the community can continue their agricultural activities on the land, while Perum Perhutani can also do land conservation activities. Conflict resolution was taken to overcome this conflicts in Genteng Village seemed slow. One of the causes was the lack of knowledge, understanding and skills to do conflict resolution from the actors involved. On the other hand, conflict resolution is clearly written in Law Number 7 of 2012 about Managing of Social Conflicts.

Other than the experience in conflict resolution efforts, currently Genteng Village is also confronted with various potential social conflicts. For example, natural resource use conflicts, political conflicts, conflicts among youths, and various other social conflicts. In this case, conflict prevention efforts must be solved by various parties so that the environment of Genteng Village becomes harmonious. Based on this, the PPM team noticed that it was important to conduct the socialization of Law Number 7 of 2012 about Managing of Social Conflicts as efforts to create a harmonious environment in the village. This article will describe the steps 


\begin{tabular}{|c|c|c|c|c|}
\hline JURNAL & \multirow{2}{*}{ VOLUME 2 } & NOMOR 1 & HALAMAN 1-73 & $\begin{array}{l}\text { ISSN 2655-8823 }(p) \\
\text { ISSN 2656-1786 }(e)\end{array}$ \\
\hline
\end{tabular}

undertaken by PPM team in conducting these socialization activities.

\section{IMPLEMENTATION METHOD}

The method of conducting the socialization activities of Law Number 7 of 2012 about Managing of Social Conflicts as efforts to create a harmonious environment in the village is conducted by several stages, such as the preparation stage, the assessment stage, the plan of treatment stage, and the implementation activity.

\section{DISCUSSION}

The following are the stages of activities conducted by the PPM team in conducting the socialization of Law Number 7 of 2012 about Managing of Social Conflicts as efforts to create a harmonious environment im the village.

\section{PPM Preparation Stage}

The first stage in this PPM activity was the preparation. In this one, there were several activities were conducted, such as the team making meeting, the assessment team coordination meeting, the permit process to the location of the activity, and the meeting to prepare the assessment instrument. In the team making meeting, the field workers was listed to assist the PPM activity. There were 12 field staffs in this activity and coming from graduate and undergraduate students from the Social Welfare Study Program, Faculty of Social and Political Sciences, Universitas Padjadjaran, and ten students who were doing Community Service Program (KKN) from the Faculty of Agriculture, Faculty of Law, Faculty of Medicine, Faculty of Nursing, Faculty of Humanities, and Faculty of Communication.

After the team making meeting, the next activity was the team coordination meeting for the assessment of PPM locations. In this meeting, it was agreed that the PPM location assessment would be conducted using two methods, firstly through a public discussion activity with the theme "Agraria Conflict Resolution Model Based on Community in Farming Communities in Genteng Village, Sukasari District, Sumedang Regency". This title was chosen because the PPM Team wanted to see how far the intention from community to do conflict resolution. Conceptually, community-based conflict resolution itself is an approach that seeks to empower groups and institutions at the local community level by giving people direct control over decision making, action planning, implementation and monitoring, through processes that emphasize participation and inclusive management of local community in an effort to resolve a Haider conflict (2009).

This public discussion invited local community leaders in Genteng Village, land practitioners and academics who had competence in conflict and conflict resolution study. This activity was held on July 8, 2019. The second assessment method was a field survey to Genteng Village through observation, interviews and documentation study. The target informants consisted of the Genteng Village government and the heads of social institutions in the Genteng Village. In this meeting, the tasks distribution for each field worker was conducted in preparation of invitations for interviewees and letter for permitting asking into PPM locations.

The next activity was permitting process to the location of activities and giving invitations for public discussion speakers. Permitting was made to the Genteng Village government as the location of PPM activities. The permitting process was accomodated by the Secretary of Genteng Village and the Head of the People's Welfare Section of Genteng Village. In addition to permitting for PPM activities, the team also invited representatives of the Genteng Village to attend as key speakers in public discussion activities. Furthermore, invitations from other public discussion speakers were given to the Head of the Sumedang 


\begin{tabular}{|c|c|c|c|c|}
\hline JURNAL & \multirow{2}{*}{ VOLUME 2 } & \multirow{2}{*}{ NOMOR 1 } & HALAMAN 1-73 & $\begin{array}{l}\text { ISSN 2655-8823 }(p) \\
\text { ISSN 2656-1786 }(e)\end{array}$ \\
\hline
\end{tabular}

District National Land Agency and academics from the Department of Sociology, Faculty of Social and Political Sciences, Universotas Padjadjaran

The next preparation was an assessment instrument preparation meeting. In this meeting, the PPM team prepared guidelines for public discussion that was used by moderators to guide public discussion activities. Furthermore, the team also compiled observation guidelines and interview guidelines which was used by field officers as a guide when conducting field surveys. In this meeting, also the list of secondary data requirements that was collected during the field survey activities.

\section{Assesment Stage}

The assessment was conducted using two methods, such as public discussion and field surveys. The first method was public discussion. This public discussion activity was held on July 8, 2019 at the Seminar Room of Faculty of Political and Social Science, Universitas Padjadjaran. The theme of the public discussion conducted was "Agraria Conflict Resolution Model Based on Community in Farming Communities in Genteng Village, Sukasari District, Sumedang Regency". Public discussions were held to explore preliminary data on agrarian conflicts and its conflict resolution based on the views of two practitioners and one academic person. Practitioners were represented by Mr. Hedi Juhaedi, Head of the Genteng Village People's Welfare Section and Mr. Deden, Head of the Land Affairs Division of the Sumedang District National Land Agency. Meanwhile the academician was represented by Dr. Wahju Gunawan from the Department of Sociology, Faculty of Political and Social Science, Universitas Padjadjaran. While the moderator was Mr. Maulana Irfan from the Center for Conflict Studies and Conflict Resolution of of Faculty of Political and Social Science, Universitas Padjadjaran.
From this public discussion activity, we listed primary data related to agraria conflict resolution model based on community in farming communities in Genteng Village, Sukasari District, Sumedang Regency as follows:

a. There was a miscommunication between people in Genteng Village and Perum Perhutani in the use of land.

b. The conversion of forest land functions that occurred in the East Manglayang Region urged people in Genteng Village shifted their professions.

c. In conflict resolution efforts, Forest Village Community Institution (LDMH) has a very important role, it was becoming the mediator between farmers and Perum Perhutani.

d. Mediation conducted by LMDH created a new consensus, it was Perhutani allowed local farmers to reclaim land in the forest area, but with certain types of plants that have been determined by Perum Perhutani.

e. In an effort to minimize agrarian conflicts, BPN undertook land certification and land redistribution, especially in potential areas of agrarian conflicts, it was at the Jatigede Dam construction site, and the Cisumdawu toll road construction site.

f. The problems that occured in Genteng Village were not just land use conflicts, but more than that, it was also about PDAM water management, the potential of job loss, land conflicts, poverty, awareness of environmental preservation, and difficulties in marketing agricultural products.

g. The efforts to solve problems in Genteng Village have been conducted by various parties through preventive and repressive 


\begin{tabular}{|c|c|c|c|c|}
\hline JURNAL & \multirow{2}{*}{ VOLUME 2} & \multirow{2}{*}{ NOMOR 1 } & HALAMAN 1-73 & $\begin{array}{l}\text { ISSN 2655-8823 }(p) \\
\text { ISSN 2656-1786 }(e)\end{array}$ \\
\hline
\end{tabular}

legal efforts, the formation of new consensus and social integration also cooperation with universities through community service programs.

h. The efforts to resolve conflicts in Desa Genteng could be done through community empowerment.

The second assessment method was a field survey to Genteng Village. This field survey was conducted by field observations, interviews with the Genteng Village Government and the heads of community organizations in Genteng Village and by interpreting the documentation of secondary data at the Genteng Village Office. The purpose of this field survey was to identify local institutions in Genteng Village and their problems also potential in development that could be used in agraria conflict resolution model based on community in farming communities. In this field survey, both PPM team members and field staff were actively involved. The results of the field survey showed that in Desa Genteng there were 13 local institutions that functioned to conduct village autonomy. The thirteen local institutions exsisted were the Village Community Empowerment Agency (LPMD), the Village Consultative Body (BPD), the Forest Village Community Institute (LMDH), Youth Organization, Bhabinkamtibmas, Bhabinsa, Vegetable Farmers Group, Coffee Farmers Group, Rice Farmers Group, Farmers Group Tobacco, Field Agricultural Extension Livestock Group (PPL) and Family Welfare Programme (PKK).

Based on the results of the field survey, the thirteen local institutions basically had their respective problems in accordance with their duties and functions. These problems were both internal and external. Internal problems generally consisted of membership issues, organizational structure and management. In the matter of membership, in almost every institution there were members who were not active in doing their obligations as members. Furthermore, on the issue of organizational structure in general, the organizational structure in each institution has not been clearly arranged. This resulted in the organizational management of the institution also did not yet have a clear job desk for each board, there was no clear standard operating procedure and no clear administrative records in the institution. These problems often also cause internal conflicts between members in the institution.

For external problems, most institutions did not yet have a strong external network to support institutional development. This often became an obstacle to the development of the potential and resources of the institution. Furthermore, another external problem was that conflicts often occurred among institutions. Conflicts between institutions that have occurred such as conflicts between coffee farmers and rice farmers. Coffee farmers who worked on independenr coffee processing often dumped the liquid waste from washing coffee beans directly into the sewer and flowed into paddy field owned by farmers. Coffee waste was hard, so it could damage the growing paddy plants. This caused conflict between the two groups. Another conflict that had also occurred was social jealousy when one group got help from the government such as assistance in farming tools, fertilizer assistance, seedling assistance, etc. In this field survey also mentioned the agrarian conflict that had occurred, it was the conflict between the farming community and Perum Perhutani.

Besides the internal and external problems of the local institution. The results of the field survey also found that local institutions in Desa Genteng were very important to be the pioneers in creating a harmonious village environment, when agrarian conflicts happened, they involved in conflict resolution efforts based on their abilities and potential until finally the agrarian 


\begin{tabular}{|c|c|c|c|c|}
\hline JURNAL & \multirow{2}{*}{ VOLUME 2 } & \multirow{2}{*}{ NOMOR 1 } & HALAMAN 1-73 & $\begin{array}{l}\text { ISSN 2655-8823 }(p) \\
\text { ISSN 2656-1786 }(e)\end{array}$ \\
\hline
\end{tabular}

conflict could be resolved. In addition in conflicts resolutions, currently Genteng Village also confronts with various potential social conflicts. For example, natural resource use conflicts, political conflicts, conflicts among youths, and various other social conflicts. In this case, a change must be made by various parties, so that the Genteng Village Environment becomes safe and harmonious. The experience in conflict resolution also the potential this issue may happen again in the future encourage the people to create harmonious environment and it must be supported by increasing the knowledge and skills of each member of the institution so that it can be conducted optimally. This is because, people who are members of these local institutions, still have limited knowledge and skills in conflict resolution and in the effort to create a harmonious environment.

\section{Plan of Treatment Stage}

Based on the results of the assessment that has been conducted, four main points related to conflict and harmony environment in Genteng Village were listed. First, in the Genteng Village there have been agrarian conflicts and other social conflicts. Second, the community through local institutions in the Genteng Village was be able to make various conflict resolution efforts. Third, local institutions could potentially make conflict resolution efforts and create a harmonious village environment. Fourth, to conduct an effective conflict resolution and create a harmonious environment, it needed to increase community knowledge and skills. Based on the points of the results of the assessment, the solution was to conduct socialization of Law Number 7 of 2012 about Managing of Social Conflicts as am effort to create a harmonious village environment.

The PPM activity aimed to increase the knowledge, understanding and skills of the target group in conducting conflict resolution in accordance of Law Number 7 of 2012 about Managing of Social Conflicts. Second, it also aimed to increase the knowledge, understanding and skills of the target groups in conducting community-based conflict resolution. Third, it aimed to encourage the target groups to prevent conflicts and to maintain the harmony of the village environment. The target groups in this PPM activity were the farming community, village government and local institutions in the Genteng Village. The stages of implementation of this activity were the preparation stage, the regional mapping stage, the PPM implementation stage, and the monitoring also evaluation.

This socialization activity conducted at Faculty of Political and Social Science, Universitas Padjadjaran. It was held as workshop with two sessions in and inviting various speakers. It was started with a presentation from the Chairperson of the PPM Team related to the Socialization of Law Number 7 of 2012 about Managing of Social Conflicts in Efforts to Create a Harmony Village Environment. The first session speakers were the heads of local institutions in Desa Genteng. While the audience in the first session were students and academician from Faculty of Political and Social Science, Universitas Padjadjaran, representatives of relevant agencies from the Sumedang District Government, agrarian activists in Sumedang Regency and representatives from Non-Government Organizations that focus on agrarian issues in Sumedang Regency. The objective from this first session was to let the speakers explained the condition of the local institutions and agrarian resources in the Genteng Village, along with the problems, potentials and various needs in context of the development. The second session speakers were practitioners from the heads of related agencies in the Sumedang District Government and academician from Faculty of Political and Social Science, Universitas Padjadjaran. The purpose of this second session was the 


\begin{tabular}{|c|c|c|c|c|}
\hline JURNAL & \multirow{2}{*}{ VOLUME 2 } & \multirow{2}{*}{ NOMOR 1 } & HALAMAN 1-73 & $\begin{array}{l}\text { ISSN 2655-8823 }(p) \\
\text { ISSN 2656-1786 }(e)\end{array}$ \\
\hline
\end{tabular}

practitioner speakers could explain the various programs owned by their respective offices that could be adopted by $\mathrm{t}$ Genteng Village community. While academician speakers were expected to be able to provide a theoretical understanding of policy and optimize the role of the community in creating a harmonious village environment.

\section{PPM IMPLEMENTATION ACTIVITY STAGE}

PPM activities in the form of a workshop entitled Dissemination of Law Number 7 of 2012 about Managing of Social Conflicts in Efforts to Create a Harmony Village Environment was held on Tuesday, July 23, 2019 at Faculty of Political and Social Science, Universitas Padjadjaran. The activity began with remarks and presentations from the PPM team leader as well as the Head of the Center for Conflict Studies and Conflict Resolution of Faculty of Political and Social Science, Universitas Padjadjaran, Dr. Soni Akhmad Nulhaqim, S. Sos., M.Si with the material "Building a Harmonious Village Environment and Socialization of Law Number 7 of 2012 about Managing Social Conflicts". Then the activity continued with the first session of the workshop. The speakers in this first session were 13 heads of local institutions in the Genteng Village with the title "Developing a Harmony Village Environment: Learning from Genteng Village, Sukasari District, Sumedang Regency". The second speaker was from the academics of the Social Welfare Department, Faculty of Political and Social Science, Universitas Padjadjaran, Mr. Sahadi Humaedi, S. Sos., M.Sc. In this first session of discussion, the moderator was Dr. Eva Nuriyah Hidayat, S. Sos., M.Sc from the Social Welfare Department, Faculty of Political and Social Science, Universitas Padjadjaran, and Mr. Drs. Saifullah Zakaria from the Department of Anthropology, Faculty of Political and Social Science, Universitas Padjadjaran.
Next, the second session continued after the lunch break. The second session was moderated by Dr. Dr. Drs. Rahman Mulyawan, M.Sc. from the Department of Government Science Faculty of Political and Social Science, Universitas Padjadjaran. The first speaker in this second session was Dr. Muhammad Fedryansyah, S. Sos., M.Si from Social Welfare Department of Faculty of Political and Social Science, Universitas Padjadjaran with the title of "Strengthening Policies in Building a Harmony Village Environment". Furthermore, the second session of the workshop was followed by a presentation entitled "Harmonization of Various Government Programs in Building a Harmony Village Environment" which was delivered by five practitioners' speakers. The five speakers were the Head of Genteng Village, Sukasari District, Sumedang Regency, represented by $\mathrm{Mr}$. Hedi Juhaedi, the Head of the People's Welfare Section of Genteng Village; Head of the Agriculture and Food Security Service of Sumedang Regency, represented by Mr. Ir. Dudi Daryadi, MM Head of Plantations at the Agriculture and Food Security Office of Sumedang Regency; Head of the Sumedang Regency Regional Development, Research and Development Planning Agency represented by Mr. Cucu Nurpirman, AP Head of Government and Social Affairs Division of the Sumedang Regency BAPPPPEDA; and the Head of Perhutani KPH Sumedang, represented by Mr. Agus Kurnia, S.Hut Deputy Administrator of the Sumedang Forest Management Unit.

This workshop was successful in increasing knowledge and skills to the community related to conflict resolution and efforts to create a harmonious environment. In addition, this workshop also succeeded in bringing together the Genteng Village community along with academics and the government. The public could find out various programs that were owned by the government and the 


\begin{tabular}{|c|c|c|c|c|}
\hline JURNAL & \multirow{2}{*}{ VOLUME 2 } & \multirow{2}{*}{ NOMOR 1 } & HALAMAN 1-73 & $\begin{array}{l}\text { ISSN 2655-8823 }(p) \\
\text { ISSN 2656-1786 }(e)\end{array}$ \\
\hline
\end{tabular}

community also got feedback from academics in efforts to solve problems and develop their potential. For the government, this workshop was useful to know the existing conditions that happened in the community as guidelines of policies making. For academician, this workshop activities were useful as a tool for scientific development.

\section{SUGGESTION AND CONCLUCION Conclucion}

Based on the further discussion, the PPM activities were conducted through four main stages, as follows:

a. Preparation phase. This stage consisted of team making meetings, assessment team coordination meetings, asking for permit to the location of activities and meetings to prepare assessment instruments.

b. Assessment stage. This stage was conducted using two methods, such as public discussion and field surveys.

c. Plan of treatment stage. Based on the results of the assessment, the solution (plan of treatment) was conducted to do socialization of Law Number 7 of 2012 about Managing of Social Conflicts as effort to create a harmonious village environment.

d. Stage of activity implementation. This stage was conducted through a workshop which was splitted into 2 main sessions. The activity began with remarks and presentations from the PPM team leader as well as the Head of the Conflict and Conflict Resolution Study Center Faculty of Social and Political Sciences, Universitas Padjadjaran, with the material "Building a Harmonious Village Environment and Dissemination of Law Number 7 of 2012 about Managing of Social Conflicts". Then continued with the first session with 13 speakers from the local institution of Genteng Village, entitled "Building a Harmonious Village Environment: Learning from Genteng Village, Sukasari Subdistrict, Sumedang District" and material on "Community Empowerment in Building Harmony in a Harmony Village" delivered by academician. In the second session, the academician gave a presentation on "Strengthening Policies in Building a Harmony Village Environment". While the material on "Harmonization of Various Government Programs in Building Harmony Village Environments" was delivered by five practitioners from Sumedang District Government.

\section{Suggestions}

Based on the conclusions above, the suggestions that can be given by PPM Team is the Genteng Village community through existing local institutions must be able to make efforts aimed at creating a harmonious village environment. When conflicts happen in the community, conflict resolution must be pursued through community-based conflict resolution by optimizing the role of local institutions. As a development of this PPM activity, it is highly aspired that in the following year the PPM team will be able to hold similar activities by focusing on developing an early warning system for social conflict in rural areas.

\section{REFERENCES}

Chandra, R. (1992). Konflik Dalam Kehidupan Sehari-Hari. Yogyakarta: Kanisius.

Haider, H. (2009). Community-based Approaches to Peacebuilding in Conflict-affected and Fragile Contexts. Retrieved from http://epapers.bham.ac.uk/642/ 


\begin{tabular}{|c|c|c|c|c|}
\hline $\begin{array}{c}\text { JURNAL } \\
\text { KOLABORASI RESOLUSI KONFLIK }\end{array}$ & VOLUME 2 & NOMOR 1 & HALAMAN 1-73 & $\begin{array}{r}\text { ISSN 2655-8823 }(p) \\
\text { ISSN 2656-1786 }(e)\end{array}$ \\
\hline
\end{tabular}

Nulhaqim, Soni Akhmad, Hidayat, Eva Nuriyah, Fedryansyah, Muhammad. 2019. Laporan Akhir Pengabdian Kepada Masyarakat (PPM) "Sosialisai UU No 7 Tahun 2012 tentang Penanganan Konflik Sosial di Desa Genteng Kec. Sukasari Kab. Sumedang”. Jatinangor: FISIP Universitas Padjadjaran.

Permadi, I. (2016). Perlindungan Hukum Terhadap Petani Penggarap Tanah Negara Milik PERUM PERHUTANI. Jurnal Arena Hukum, 9(2), 225-251. doi:10.21776/ub.arenahukum.2016.009 02.5

Profil Desa Genteng Kecamatan Sukasari Kabupaten Sumedang Tahun 2019.

Zakie, M. (2016). Konflik Agraria yang Tak Pernah Reda. Jurnal Legality, 24(1), 40-45. doi:10.22219/jihl.v24i1.4256 